\title{
NEW PUBLIC MANAGEMENT IN DEVELOPING COUNTRIES: EFFECTS AND IMPLICATIONS ON HUMAN RESOURCE MANAGEMENT
}

\author{
Mo'men Hani Mahmoud ${ }^{1},{ }^{*}$, Rosly Othman ${ }^{1}$ \\ ${ }^{1}$ Graduate School of Business, Universiti Sains Malaysia, 11800 Penang, Malaysia
}

ABSTRACT - This paper performs a Systematic Literature Review (SLR) to explore the linkage between New Public Management (NPM) reforms and Human Resource Management (HRM). Accordingly, 24 papers from 2015 to 2020 were selected to discuss three major issues in 19 developing countries, namely the implementation of NPM reforms, gaps and challenges of NPM, and the effects and implications of these gaps and challenges on HRM. The findings revealed that public services remain unsatisfactory and fail to meet public expectations despite optimising public services. The originality of this paper is that it investigates the latest NPM reforms. Therefore, it provides a valuable source for academics and practitioners alike to address the gaps and challenges of NPM reforms. It concludes by highlighting three contemporary knowledge gaps of NPM components and their links with HRM as future directions in this field.

\author{
ARTICLE HISTORY \\ Received: $21-11-2020$ \\ Revised: 4-1-2021 \\ Accepted: $18-2-2021$

\section{KEYWORDS} \\ New Public Management \\ Reforms (NPM), \\ Human Resource \\ Management (HRM), \\ Public services, \\ Public organisations, \\ Developing countries
}

\section{INTRODUCTION}

Despite the ongoing efforts to improve public services in developing countries by incorporating the New Public Management (NPM) reforms into public organisations, public service delivery remains unsatisfactory and has yet to meet public expectations. This can be attributed to a conspicuous gap between the ideal implementation and the actual implementation of NPM reforms (Tioumagneng \& Njifen, 2019). Public services refer to all public services, goods, and programmes delivered to the public by public organisations to fulfil their desired expectations and meet their interests (Mahmoud et al., 2020; Turner et al., 2019). Accordingly, public organisations include all entities that are governmentally owned, controlled, or funded bodies, agencies, and institutions responsible for delivering public services in a certain context (Mahmoud et al., 2020; Thompson, 2017). Furthermore, NPM reforms are identified as a set of reforms and initiatives introduced predominantly in local agencies and municipal administrations to deliver improved public services and develop the strategic management of these entities (Pavan et al., 2014; Rosenberg Hansen \& Ferlie, 2016). The adoption of the NPM has introduced the business-like practices of private organisations to improve the efficiency and effectiveness of the public sector (Blom et al., 2020; Fryer et al., 2009; Roh, 2018). The NPM ideology refers to the government's policy and analysis that manage and regulate public entities (Dunleavy et al., 2006), and all systems and practices related to stakeholder concerns such as goal achievement, management style, and professionalism (Dunleavy \& Hood, 1994).

In developing countries, public organisations are inconsistent in implementing public services reforms to improve the organisations' skills, efficacy, and efficiency in delivering better-quality public services (Ikeanyibe, 2016). Although several governments control and monitor the performance of the public sector through significant NPM reforms in public administrations, several developing countries' governments have not considered and adopted such a vision to date (Komutputipong \& Keerasuntonpong, 2019). In addition, the public organisations' inefficiency, alongside corruption scandals, are key factors for delivering poor public services to citizens in developing countries due to the governments' weak accountability (Shaheen et al., 2017). Moreover, in many developing countries, the NPM reforms are dead letter reforms, for example, planning, measurement, evaluation, rewarding, resource allocation, public satisfaction, and budgeting are for results purposes only (Ikeanyibe, 2016; Ramos \& Milanesi, 2020). Scholars also mentioned that several gaps and challenges prevented implementing these reforms, including lack of transparency, poor analytical skills, poor enforcement of decisions, and poor legal framework (Guga, 2018). NPM reforms also varied broadly from one country to another (Leisink \& Knies, 2018), with a significant disparity between the implementation of such reforms between developed and developing countries (Aoki, 2019). In this regard, the existing gaps and challenges of implementing NPM reforms by public organisations have significantly affected public servants' behaviours, conditions, and performance by developing, motivating, and assessing the performance via HRM practices and policy towards public organisations' performance (i.e., public services) (Cantarelli et al., 2020; Fletcher et al., 2020). This finding underscores that employees are a vital resource in achieving excellent performance in organisations (Delaney \& Huselid, 1996).

This paper, therefore, critically reviews the NPM reforms in developing countries. It discusses three major issues, namely the implementation of the NPM reforms, the gaps and challenges encountered in implementing NPM reforms, and the effects and implications of these gaps and challenges on HRM. To this end, a Systematic Literature Review (SLR) 
has been conducted to discuss the latest reforms of public organisations in developing countries. The findings will help academics and practitioners address the gaps and challenges in implementing NPM reforms in developing countries, alongside the effects and implications of these gaps and challenges on HRM.

This paper, thereby, is organised into five sections. The first section discusses the theoretical background. The second section explains the research methodology (i.e., SLR), including data sources. The third section presents the results, including data extraction and data description. The findings are discussed in the fourth section, followed by a conclusion in the fifth section.

\section{THEORETICAL BACKGROUND}

Public administration principles represent the prominent reforms introduced in the NPM reforms (Lapuente \& Van de Walle, 2020). Regarding the definition of NPM, scholars emphasised that NPM is difficult to define as it is a concept and ideology (Barzelay, 2000; Hood, 1990, 2005). Nevertheless, the concept of NPM can be identified as any practice, activity, or method introduced and implemented in the public sector to maximise efficiency and effectiveness in the process of public services delivery (Dunleavy et al., 2006). Relatively, scholars agreed that the common concept of NPM involves incorporating private sector management into the management of public services (Haynes, 2003; Pollitt, 1993). Thus, NPM can be recognised as a set of characteristics, reforms, practices, or themes of public administrations to deliver quality public services (Lodge \& Gill, 2011).

Scholars have referred to the NPM reforms through several elements, including clear measures of performance and further emphasis on public services, enabling decentralising activities, disposing of bureaucratic structures, developing qualified staff, behaving like private sector organisations, and raising competition among the sub-units of public organisations (Fryer et al., 2009; Roh, 2018). These NPM elements have translated into several reforms, including postbureaucracy government, additional focus on accountability, the entitlement-based relationship between citizens and the state, results-based management, professionalism, cooperation between public and private sectors, managing inputs and outputs of performance, and enhancing public satisfaction (Turner et al., 2019; Ugyel, 2014).

It is worth mentioning that the NPM refers to three main components, namely incentivisation, competition, and disaggregation (Dunleavy et al., 2006). The incentivisation component refers to rewarding specific rather than the general performance of public entities using a flat and consistent salaries scale against a commitment to organisational values (Miller, 2000). The competition component explains that public entities tend to staff the best public servants who are highly motivated towards achieving superior public services (Hood, 1995; Le Grand, 2003). The disaggregation component discusses the division, decoupling, or subunit towards a broad mission that focuses on the delivery of public services, that, in turn, would enhance performance results and improve accountability (Dunleavy \& Hood, 1994). The idea is that granting managerial freehand to public units will strengthen the central control on performance results (Pierre, 2000). More specifically, the government determines the service that should be delivered "what", while the sub-units are free to determine how those services are delivered "how" (Osborne \& Gaebler, 1992). In other words, the HRM unit should have the autonomy to deliver services efficiently (Suhail \& Steen, 2018).

Most importantly, HRM is the backbone of any organisation, and HR practices and policies are significant concerns of the public sector regarding staff performance (Truss, 2013). However, academic research regarding the role of efficient HRM practices and policy towards improving public service delivery are limited (Knies \& Leisink, 2018), particularly in developing countries (Suhail \& Steen, 2018). HRM is a set of management decisions about practices and policies that shape public servants' efforts and contributions to achieve specific goals (Boselie et al., 2019). In addition, the shape of the HRM of public organisations differs according to the implemented NPM reforms (Knies \& Leisink, 2018).

In the developing world, the gaps between planned and actual reforms are leading causes for failed public services delivery (Tioumagneng \& Njifen, 2019). Nevertheless, research on the implementation of NPM reforms in developing countries has been investigated from the perspectives of multiple entities. These entities consist of the federal public organisations (Zahra \& Jadoon, 2016), local government (Ahenkan et al., 2018; Guga, 2018; Ikeanyibe, 2016; Mussagulova \& Van der Wal, 2019; Nyamori \& Gekara, 2016; Tioumagneng \& Njifen, 2019; Ukeje et al., 2020), health sector (Bobe et al., 2017; Errami \& Cargnello, 2018; Mostafa, 2016; Powell-Jackson et al., 2019), education and transport sectors (Bhiwajee \& Garavan, 2016), government ministries (Bianchi \& Xavier, 2017; Gupta et al., 2018; Shaheen et al., 2017), and the central government (Osei-Kojo, 2017; Ramos \& Milanesi, 2020; Sarker \& Al Athmay, 2018; Siddiquee et al., 2019; Sutheewasinnon et al., 2016; Turner et al., 2019; Ustuner \& Yavuz, 2018; Vu et al., 2019).

Most importantly, the prominent NPM reforms introduced into the public entities in the developing countries covered several aspects. These aspects are presented in Table 1.

Table 1: NPM aspect in the developing countries

NPM aspect $\quad$ Source

Autonomy (i.e., decentralisation) (Bhiwajee \& Garavan, 2016; Errami \& Cargnello, 2018; Guga, 2018; Mostafa, 2016; Powell-Jackson et al., 2019; Sarker \& Al Athmay, 2018; Tioumagneng \& Njifen, 2019; Ustuner \& Yavuz, 2018; Vu et al., 2019; Zahra \& Jadoon, 2016)

Efficiency

(Bianchi \& Xavier, 2017; Errami \& Cargnello, 2018; Guga, 2018; Nyamori \& Gekara, 2016; Osei-Kojo, 2016; Sarker \& Al Athmay, 2018; 


\begin{tabular}{|c|c|}
\hline NPM aspect & Source \\
\hline & $\begin{array}{l}\text { Siddiquee et al., 2019; Sutheewasinnon et al., 2016; Turner et al., 2019; } \\
\text { Ustuner \& Yavuz, 2018; Zahra \& Jadoon, 2016) }\end{array}$ \\
\hline Performance management system & $\begin{array}{l}\text { (Ahenkan et al., 2018; Bianchi \& Xavier, 2017; Bobe et al., 2017; Errami } \\
\text { \& Cargnello, 2018; Guga, 2018; Ikeanyibe, 2016; Mussagulova \& Van } \\
\text { der Wal, 2019; Nyamori \& Gekara, 2016; Osei-Kojo, 2016; Ramos \& } \\
\text { Milanesi, 2020; Sarker \& Al Athmay, 2018; Siddiquee et al., 2019; } \\
\text { Sutheewasinnon et al., 2016; Tioumagneng \& Njifen, 2019; Turner et } \\
\text { al., 2019; Ustuner \& Yavuz, 2018) }\end{array}$ \\
\hline Accountability & $\begin{array}{l}\text { (Ahenkan et al., 2018; Bianchi \& Xavier, 2017; Sutheewasinnon et al., } \\
\text { 2016; Turner et al., 2019; Ustuner \& Yavuz, 2018; Vu et al., 2019; } \\
\text { Zahra \& Jadoon, 2016), HRM reforms (Bhiwajee \& Garavan, 2016; } \\
\text { Bianchi \& Xavier, 2017; Bobe et al., 2017; Guga, 2018; Gupta et al., } \\
\text { 2018; Ikeanyibe, 2016; Mostafa, 2016; Ramos \& Milanesi, 2020; } \\
\text { Siddiquee et al., 2019; Tioumagneng \& Njifen, 2019; Turner et al., } \\
\text { 2019; Ukeje et al., 2020; Vu et al., 2019) }\end{array}$ \\
\hline Post-bureaucracy & $\begin{array}{l}\text { (Bhiwajee \& Garavan, 2016; Bianchi \& Xavier, 2017; Errami \& Cargnello, } \\
\text { 2018; Siddiquee et al., 2019) }\end{array}$ \\
\hline Responsibility & $\begin{array}{l}\text { (Errami \& Cargnello, 2018; Gupta et al., 2018; Mussagulova \& Van der } \\
\text { Wal, 2019; Ramos \& Milanesi, 2020; Sarker \& Al Athmay, 2018; } \\
\text { Sutheewasinnon et al., 2016; Tioumagneng \& Njifen, 2019; Ustuner \& } \\
\text { Yavuz, 2018; Zahra \& Jadoon, 2016) }\end{array}$ \\
\hline Quality & $\begin{array}{l}\text { (Bhiwajee \& Garavan, 2016; Bianchi \& Xavier, 2017; Ikeanyibe, 2016; } \\
\text { Siddiquee et al., 2019; Powell-Jackson et al., 2019; Ustuner \& Yavuz, } \\
\text { 2018) }\end{array}$ \\
\hline Legal reforms & $\begin{array}{l}\text { (Bianchi \& Xavier, 2017; Bobe et al., 2017; Guga, 2018; Sarker \& Al } \\
\text { Athmay, 2018; Turner et al., 2019; Ustuner \& Yavuz, 2018) }\end{array}$ \\
\hline Effectiveness & (Turner et al., 2019; Ustuner \& Yavuz, 2018) \\
\hline Transparency (i.e., audit body) & (Guga, 2018; Ikeanyibe, 2016; Ustuner \& Yavuz, 2018) \\
\hline Public satisfaction and feedback & $\begin{array}{l}\text { (Bhiwajee \& Garavan, 2016; Bianchi \& Xavier, 2017; Bobe et al., 2017; } \\
\text { Errami \& Cargnello, 2018; Guga, 2018; Ikeanyibe, 2016; Mussagulova } \\
\text { \& Van der Wal, 2019; Nyamori \& Gekara, 2016; Osei-Kojo, 2016; } \\
\text { Powell-Jackson et al., 2019; Ramos \& Milanesi, 2020; Sarker \& Al } \\
\text { Athmay, 2018; Siddiquee et al., 2019; Sutheewasinnon et al., 2016; } \\
\text { Turner et al., 2019; Ukeje et al., 2020; Ustuner \& Yavuz, 2018; Vu et } \\
\text { al., 2019) }\end{array}$ \\
\hline
\end{tabular}

Given the significant changes that these reforms have spurred and their influence on the HRM of public entities, there is a need to investigate HRM practices and policies, including the way of regulating, managing, rewarding, developing, and evaluating public servants' performance (Leisink \& Knies, 2018).

\section{METHODOLOGY}

This paper conducted a Systematic Literature Review (SLR) of selected ISI/SCOPUS-indexed journals using specific search terms, during specific periods, and depending on five main databases as follows:

- Search Terms: ("NPM" OR "New Public Management") AND ("Public Organisations" OR "Public Services") AND ("Human Resource Management" OR "HRM") AND "Developing Countries". These search terms were used to locate relevant scholarly papers on the relevant topic.

- Search Period: A specific period (from 2015 to 2020) was identified for the review to locate the latest introduced NPM reforms and HRM status. Ikeanyibe (2016) stated that public services reforms are inconsistent and imperfect in developing countries. In addition, the latest reforms in the developing countries were introduced as a strategy during this specific period (Guga, 2018). Also, scholars confirmed that the public organisations' services reforms mainly rely on the current fitness of initiatives and elements for developing public administrations (Turner et al., 2019).

- Databases: Five major databases were visited for the review, including Emerald Insights, Sage Journals, ScienceDirect, Taylor \& Francis, and Wiley Online. These databases include the ISI/SCOPUS-indexed journals.

The SLR primary results identified (176) published papers. To further proceed with the current review, Kitchenham et al. (2009) argued that SLR depends on the following seven steps, according to which, only (24) papers were eligible for review.

- $\quad$ Step 1: Includes all the papers revealed in accordance with search terms (176).

- $\quad$ Step 2: Includes all the papers related to the review's topic according to the papers' title and abstract (85).

- $\quad$ Step 3: Includes all the papers with neglecting duplicated papers based on Step 1 and 2 (85).

- $\quad$ Step 4: Includes all the papers which initially fit following the review's purpose, context, and findings based on the introduction and conclusion (44). 
- Step 5: Includes all the papers which are discussed the implementation of the NPM reforms in the developing countries in accordance with fully reading (24).

- Step 6: Includes all the papers after conducting the quality assessment process that undergoes the three questions that were used by Ain et al. (2019) and Azhar et al. (2012):

1. Has the research's aim been clearly stated?

2. Has the research's context been sufficiently explained?

3. Has the research's methodology been adequately discussed?

Additionally, all papers that scored more than (80\%) were included in the review based on specific results (i.e., Yes $=1$, Partly $=0.5$, No $=0$ ). Accordingly, the total number of papers included in the current SLR is (24) published papers. After that, all the qualified (24) papers were shifted to the last step (i.e., the seventh step).

- $\quad$ Step 7: Includes all papers used in the current SLR (i.e., final papers) (24).

In this paper, the data sources can be identified as databases, journal name, topic, and the number of scholarly published papers. The selected (24) papers were sourced from five databases and (16) ISI/SCOPUS-indexed journals, as illustrated in Table 2 .

Table 2: Data sources of the SLR

\begin{tabular}{|c|c|c|}
\hline Database & Journal's name & Paper's topic \\
\hline \multirow{6}{*}{$\begin{array}{l}\text { Emerald } \\
\text { Insights }\end{array}$} & International Journal & Local Government Modernisation \\
\hline & of Public Sector & Background and the Territorial Reform 2015 - 2020; Autonomy \\
\hline & Management & of public agencies in Pakistan: does structure matter? \\
\hline & $\begin{array}{l}\text { International Journal } \\
\text { of Productivity and } \\
\text { Performance } \\
\text { Management }\end{array}$ & $\begin{array}{l}\text { Performance management implementation challenges in Ghana's } \\
\text { local government system: evidence from the Sefwi Wiawso } \\
\text { municipal assembly }\end{array}$ \\
\hline & $\begin{array}{l}\text { Accounting, } \\
\text { Auditing \& } \\
\text { Accountability } \\
\text { Journal }\end{array}$ & $\begin{array}{l}\text { Public sector reforms and balanced scorecard adoption: an } \\
\text { Ethiopian case study }\end{array}$ \\
\hline & $\begin{array}{l}\text { European Journal of } \\
\text { Training and } \\
\text { Development }\end{array}$ & $\begin{array}{l}\text { The empowering of public sector officers in the Mauritian public } \\
\text { sector in the context of reforms: How far has management } \\
\text { education helped? }\end{array}$ \\
\hline \multirow[t]{2}{*}{$\begin{array}{l}\text { Sage } \\
\text { Journals }\end{array}$} & $\begin{array}{l}\text { International Review } \\
\text { of Administrative } \\
\text { Sciences }\end{array}$ & $\begin{array}{l}\text { Employee involvement in the public administrative sector: an } \\
\text { exploration of the engagement drivers in Cameroon; The neo- } \\
\text { Weberian state and the neo-developmentalist strategies in Latin } \\
\text { America: the case of Uruguay }\end{array}$ \\
\hline & $\begin{array}{l}\text { Public Personnel } \\
\text { Management }\end{array}$ & $\begin{array}{l}\text { Examining Organisational Cronyism as an Antecedent of } \\
\text { Workplace Deviance in Public Sector Organisations }\end{array}$ \\
\hline \multirow[t]{2}{*}{$\begin{array}{l}\text { Science- } \\
\text { Direct }\end{array}$} & $\begin{array}{l}\text { Critical Perspectives } \\
\text { on Accounting }\end{array}$ & $\begin{array}{l}\text { Development of a performance management system in the Thailand } \\
\text { public sector: Isomorphism and the role and strategies of } \\
\text { institutional entrepreneurs; Performance contracting and social } \\
\text { capital (re)formation: A case study of Nairobi City Council in } \\
\text { Kenya }\end{array}$ \\
\hline & $\begin{array}{l}\text { Social Science \& } \\
\text { Medicine }\end{array}$ & $\begin{array}{l}\text { Measuring management practices in India's district public health } \\
\text { bureaucracy }\end{array}$ \\
\hline \multirow[t]{5}{*}{$\begin{array}{l}\text { Taylor \& } \\
\text { Francis }\end{array}$} & $\begin{array}{l}\text { International Journal } \\
\text { of Public } \\
\text { Administration }\end{array}$ & $\begin{array}{l}\text { New Public Management and Administrative Reforms in Nigeria; } \\
\text { Public Service Recruitment Practices and Implications for } \\
\text { Sustainable Development in Ebonyi State, Nigeria; The } \\
\text { Changing Facets of Public Administration in the United Arab } \\
\text { Emirates; The Design and Execution of Performance } \\
\text { Management Systems at State Level: A Comparative Analysis } \\
\text { of Italy and Malaysia; Turkey's Public Administration Today: } \\
\text { An Overview and Appraisal; What Works and Why? Lessons } \\
\text { from Public Management Reform in Malaysia }\end{array}$ \\
\hline & $\begin{array}{l}\text { Journal of Asian } \\
\text { Public Policy }\end{array}$ & $\begin{array}{l}\text { Leadership competencies for effective public administration: a } \\
\text { study of Indian Administrative Service officers }\end{array}$ \\
\hline & $\begin{array}{l}\text { Policy Design and } \\
\text { Practice }\end{array}$ & $\begin{array}{l}\text { Reforming while maintaining job security: a good idea? The case of } \\
\text { the Kazakhstani public service }\end{array}$ \\
\hline & Policy Studies & The challenge of reforming big bureaucracy in Indonesia \\
\hline & $\begin{array}{l}\text { Public Management } \\
\text { Review }\end{array}$ & $\begin{array}{l}\text { High-Performance HR Practices, Work Stress and Quit Intentions } \\
\text { in the Public Health Sector: Does person-organisation fit } \\
\text { matter? }\end{array}$ \\
\hline
\end{tabular}




\begin{tabular}{|c|c|c|c|}
\hline Database & Journal's name & Paper's topic & No. \\
\hline \multirow[t]{3}{*}{$\begin{array}{l}\text { Wiley } \\
\text { Online }\end{array}$} & $\begin{array}{l}\text { Canadian Journal of } \\
\text { Administrative } \\
\text { Sciences }\end{array}$ & $\begin{array}{l}\text { The pertinence of new public management in a developing country: } \\
\text { The healthcare system in Morocco }\end{array}$ & 1 \\
\hline & $\begin{array}{l}\text { Journal of Public } \\
\text { Affairs }\end{array}$ & E-government and public service quality in Ghana & 1 \\
\hline & $\begin{array}{l}\text { Public } \\
\text { Administration and } \\
\text { Development }\end{array}$ & $\begin{array}{l}\text { Managing employee performance in transition economies: A study } \\
\text { of Vietnamese public organisations }\end{array}$ & 1 \\
\hline
\end{tabular}

The exclusion process across all the steps in this research depends on three criteria as follows:

1. All the papers which are not relevant to the topic, including title, abstract, context, and findings.

2. All the papers which are closed access.

3. All the papers that did not discuss the implementation of NPM reforms.

\section{THE SLR RESULTS}

The (24) papers selected for the SLR were subject to data extraction and data description. Data extraction refers to the tools used to extract data for the reviewed papers. Data description refers to the research context, the methodology used, and chronological distribution (i.e., year of publication) (Hoehle et al., 2012; Kitchenham et al., 2009). For the current systematic review, data were extracted using Microsoft Word, Microsoft Excel, and Google Scholar. On the other hand, the data description is reflected in the research context, the research methodology used, and the chronological distribution, as illustrated in Table 3 .

Table 3: Data description

\begin{tabular}{lll}
\hline Context & Methodology & Year \\
\hline Thailand & Secondary Data \& Interview & 2016 \\
India & Secondary Data \& Interview & 2018 \\
Kenya & Focus Group \& Questionnaire & 2019 \\
Ghana & Secondary Data \& Interview & 2016 \\
& Secondary Data & 2018 \\
Vietnam & Interview & 2016 \\
Morocco & Secondary Data \& Interview & 2019 \\
Egypt & Secondary Data \& Interview & 2018 \\
Nigeria & Questionnaire & 2016 \\
& Secondary Data & 2016 \\
Kazakhstan & Questionnaire & 2020 \\
Indonesia & Questionnaire & 2019 \\
United Arab Emirates (UAE) & Secondary Data & 2019 \\
Malaysia & Secondary Data & 2018 \\
& Secondary Data & 2017 \\
Turkey & Interview & 2019 \\
Cameroon & Secondary Data & 2018 \\
Uruguay & Questionnaire & 2019 \\
Pakistan & Secondary Data & 2020 \\
Albania & Questionnaire & 2017 \\
Ethiopia & Questionnaire & 2016 \\
Mauritius & Secondary Data & 2018 \\
\hline
\end{tabular}

\section{FINDINGS}

\section{The implementation of NPM reforms in developing countries}

NPM reforms have been introduced in public organisations to improve public services' quality via diverse reforms (Dunleavy et al., 2006). These reforms are concerned with implementing vital elements to deliver superior public services such as characterisation that refers to the post-bureaucratic competitive government that focuses on implementing more flexible methods of delivering improved public services. The citizen-state relationship determines the public service entitlements required to empower the community and emphasises senior officials' accountability towards the citizens who receive public services. In other words, it ensures that customers are satisfied. The dominant focus or a guiding principle relates to performance results. The relationship between delivers and receivers reflects the professionalism concept. The system delivery adopts the private sector thoughts or small public entities. The performance objectives focus 
on managing performance inputs and outputs. Lastly, the role of public participation embeds the public feedback about the delivered public services (Fryer et al., 2009; Roh, 2018; Turner et al., 2019; Ugyel, 2014).

Performance management is one of the most significant reforms introduced by NPM reforms within public organisations to modernise and deliver public services superlatively (Bianchi \& Xavier, 2017). In developing countries, however, these reforms are implemented within public organisations without considering citizens' desired expectations (Ikeanyibe, 2016). These implementations have generated several challenges and gaps, which should be addressed due to their implications that might affect organisational stakeholders (i.e., citizens and public servants) (Nyamori \& Gekara, 2016).

Public organisations strive to translate the characterisation concept in line with NPM reforms by disposing of bureaucracy generated by old public administrative practices and introducing further reforms to make their contexts competitive (Ugyel, 2014). Scholars argued that NPM reforms might increase competition between public organisations and sub-units within one organisation, performing like private organisations, enabling decentralisation, and staffing skilled professionals (Fryer et al., 2009; Roh, 2018). In an example of a developing country, the Thai government translated the characterisation concept in the implementation changes to ensure the efficiency of operations based on time, promptness, and reduction of resources in delivering public services. Moreover, the management system was involved in results-based management. The Thai government created the Office of Public Sector Development to develop, monitor, and evaluate services by multiple agencies. The government has empowered this office to create new agencies based on the service requirements across regions (Sutheewasinnon et al., 2016).

The Indian government introduced operational reforms, people management reforms, and autonomy reforms, which are significant in characterising the Indian public organisations. Operational reforms focused on the efficient use of HR. People management reforms supported, rewarded, and promoted employees' high performance and dealt with employees' poor performance. Autonomy reforms included programmes' implementation autonomy, financial allocation autonomy, and HRM autonomy (Powell-Jackson et al., 2019).

The Ghanaian government reforms focused on the efficiency of the delivered services and economic reforms. The reforms of efficiency of delivered services were manifested in the provision of public services remotely (i.e., online), gaining further benefits of reducing paperwork processes, and speeding up public services delivery. On the other hand, economic reforms maximised resources to fulfil the citizens' needs through time and cost reduction. Time reduction was achieved by reducing operational hours, whereas cost reduction was realised by reducing the cost of employees, materials, etc. (Osei-Kojo, 2016). The Ghanaian government also implemented further reforms related to the performance management system as an integral part of NPM reforms. These reforms involved creating systems and procedures for developing and evaluating public servants, particularly at the leadership level, unifying a comprehensive framew ork of public administration and its strategy of rewarding and punishing good and poor performance, respectively. Other ongoing public services improvements included emphasising public managers and employees (Ahenkan et al., 2018).

The Vietnamese government reforms focused on employees' performance management, including the agencies' autonomy in the HRM practices and developing HR competencies (Vu et al., 2019). The Moroccan government adopted a new model of NPM reforms. The aim is to be less hierarchical and oriented towards a results-based system to fit decentralised public managers' responsibility to achieve the desired objectives. The new efficiency requirements involved decreasing centralised control, improving participants' integration, providing effective ways of communication, enhancing organisational and management capacity, developing local HR competencies, and improving programme integration. These reforms have resulted in restructuring bureaucracy using sub-units' autonomy, implementing private sector methods, focusing on resources' efficiency, and supervision of multiple responsibilities (Errami \& Cargnello, 2018). The Mauritian government executed its reforms by creating sub-administrative units to reduce bureaucracy. ISO standards for best government practices on services' quality were implemented. One-stop points were established to reduce the bureaucracy delay. Lastly, public employees' competencies were improved by spending more on their skills and competencies as significant government assets (Bhiwajee \& Garavan, 2016).

The Egyptian government reforms limited the characterisation concept by adopting general reforms. These reforms included decentralisation activities, professional staff, work environment, autonomy, distinct mission, and clear goals that aligned with the employees' goals (Mostafa, 2016). In another context, the Emirati government reforms involved general reforms, including managing services efficiency, replacing traditional activities of centralisation by decentralisation activities, instilling organisational culture principles, introducing customer service reinforcement, creating performancebased orientation, updating old legislation by introducing anti-corruption legislation, and improving strategic management (Sarker \& Al Athmay, 2018). However, the Nigerian government reforms were more comprehensive, including HRM reforms, operations and systems, and value and ethics orientation. The HRM reforms involved restructuring the HR practices, including redesigning performance appraisal based on actual results, reviewing the workforce, reorganising recruitment and promotion procedures, retraining current employees, revisiting the rewards system, and hiring new qualifications. Operations and systems' reforms focused on the organisational restructuring, work process redesign, and information technology applications' introduction. Value and ethics orientation reforms focused on rebranding projects, training, and eliminating unethical practices (Ikeanyibe, 2016). Additional HRM-related reforms were achieved to obtain the best HR practices for better results by public employees, such as job satisfaction and changing employees' attitudes (Ukeje et al., 2020).

The Indonesian government reforms introduced a cultural revolution as it focused on having public servants who are competent, unbiassed, professional, high performers, and can deal with integrity principles. Accordingly, laws and regulations were modified to produce an orderly system that contributes to enhancing efficiency and ensuring that the 
most effective procedures are utilised to eliminate unethical practices (Turner et al., 2019). The Turkish government reforms focused on the state and marketplace reforms, public services reforms, and ethics reforms. The state and marketplace reforms produced the main tools to develop the economy and policy. The aim was to build a national-state, achieve top-bottom modernisation, and develop dependable administration. These reforms maximised the efficiency and productivity of the government and enabled decentralisation activities. The public services reforms focused on regulating public employment at central and local levels, preparing personnel policies, providing an overview of the workforce, and assigning HRM departments following the NPM reforms and principles. The ethics reforms mainly involved reducing corruption and ensuring the best practices to deliver services ethically (Ustuner \& Yavuz, 2018).

The Malaysian government implemented several reforms across several decades. In line with the characterisation concept of the NPM reforms, the government has recently implemented numerous reforms, including organisational structure and culture reforms that focused on establishing an independent unit for evaluation, restructuring organisations and operations to evaluate performance objectively, focusing on the results-based model, and instilling efficient practices in the public expenditure. Legislation reforms focused on establishing public bodies to monitor and control public services delivery in conformity with the laws and regulations to adopt innovative methods in delivering public services. Administrative and political leadership reforms, which have a combined role to play, focused on establishing political and administrative reforms in managing, planning, and controlling public services (Bianchi \& Xavier, 2017). In addition, Siddiquee et al. (2019) argued that the Malaysian government introduced significant reforms in public organisations, including personnel management reforms and service delivery reforms. Personnel management reforms aimed at enhancing performance efficiency by rewarding excellent results, reinforcing public services by improving services conditions, restructuring salary scales, evaluating levels of competencies, and extending the career development scope. Services delivery reforms, which embedded processes and operations, included reengineering, creating one-stop points, enabling online services, empowering customer-oriented systems, and enhancing vital services such as public transportation, education, health, and agriculture.

In another context, three major reforms were applied by the Cameroonian government regarding characterisation. They involved developing strategic goals to fulfil the citizens' needs and interests, restructuring public employees and their salaries, and improving organisational practices, including autonomy, initiatives, and responsibility (Tioumagneng \& Njifen, 2019). The Uruguayan government, like other Latin American contexts, introduced NPM reforms as neoWeberian reforms. These reforms aimed at developing a performance agreement contract by concentrating on managing performance (e.g., planning, budgeting, monitoring, and evaluation). They also aimed at establishing a managerial position at the top of the structure to strengthen the system of public services career, transparency, and the competenciesbased system (Ramos \& Milanesi, 2020). The Pakistani government focused on having good practices to achieve efficiency, accountability, and enable autonomy to empower decentralisation activities (Zahra \& Jadoon, 2016).

The Albanian government reformed its practices by focusing on staffing professional administrations, developing HR, and increasing financial resources to accomplish the national agenda. These reforms involved maximising public services' efficiency, reducing regions and municipalities bodies, enhancing autonomy tools, reinforcing local governments' abilities, and creating an audit body to monitor and evaluate the system's strategies, programmes, processes, and legal framework (Guga, 2018). In the Ethiopian context, the government made numerous reforms in the health sector. These reforms enhanced the stakeholders' satisfaction with health services by resourcing utilisation and mobilisation, strengthening partnerships, cooperation, responses, and perpetrations. The introduced reforms focused on developing employees and leaderships, reforming the legal framework, and adopting an evidence-based system for decision-making processes (Bobe et al., 2017).

The citizens-state relationship and accountability following NPM reforms are based on the entitlement principle and considering how citizens receive the services. The entitlement principle refers to public organisations' required missions to citizens, whereas accountability refers to the administrative bodies responsible for delivering public services (Ugyel, 2014). The entitlement and accountability towards delivering public services explain the resource exchange process between public organisations and citizens (Turner et al., 2019). Scholars pointed out that the most significant reform introduced by governments in public organisations involved delivering public services superiority by emphasising the system of public services (Dunleavy \& Hood, 1994; Fryer et al., 2009; Roh, 2018). Moreover, the citizens-state relationship and accountability have established the relationship between deliveries and receivers. This relationship can be described as patrimonialism (Turner et al., 2019).

The Thai government established an administrative body under the Prime Minister's office to control, gauge, evaluate, and follow all sub-administrative performance (Sutheewasinnon et al., 2016). The Kenyan government reforms involved shifting from the traditional rule-based evaluation to the comprehensive use of individual performance appraisal considering the results-based model to follow the goals' setting in ministries' operations. To perform efficiently, an administrative body for performance contracts has been created under the Prime Minister's office to develop, manage, and re-contract public services' performance and determine each public agency's promises according to the goals' setting (Nyamori \& Gekara, 2016). In the Indian context, the government identified specific competencies required by the administrators to meet public expectations. These competencies need to predict and answer the citizens' needs, reinforce and improve public services, and cultivate a public-serving culture (Gupta et al., 2018). Other reforms introduced by the Indian government involved improving the types of goals, goals' clarity, and time horizons (Powell-Jackson et al., 2019).

The Ghanaian government reforms shifted to the online mode of delivering services. The key concern was the accessibility of the services and making these public services permanently accessible to citizens online (Osei-Kojo, 2016). The Vietnamese government directed its attention towards reinforcing the entrepreneurial leadership within public 
organisations to maximise administrative accountability in line with the NPM reforms (Vu et al., 2019). Furthermore, the Moroccan government's accountability has been enhanced by studying and reviewing the organisational strategies implemented by stakeholders to increase their responsibility. Stakeholders can be empowered by providing the tools to attain measurable performance results to the administrative units (Errami \& Cargnello, 2018). The Nigerian reforms mainly involved reconsidering the installation of due processes, improving the transparency of public transactions, creating service charters, and instituting the quality of service delivery (Ikeanyibe, 2016). The Indonesian government reforms viewed accountability as a tool to increase the capacity of public services delivery and performance culture development (Turner et al., 2019). The Malaysian government's performance management system and public administration model played a significant role in increasing accountability throughout the performance management system cycle (Bianchi \& Xavier, 2017).

The system of delivery refers to the responsibility of the body (i.e., private or public agency) in delivering public services. A performance objective is a management approach used to manage performance results (i.e., managing inputs and/or outputs) (Ugyel, 2014). The Thai system is results-based, and the responsibility of delivering public services is shouldered by public agencies and sub-units (Suthee Wasinnon et al., 2016). The Indian system is a results-oriented system, and public entities are responsible for delivering public services following the regional requirements (Gupta et al., 2018). The Kenyan system also shifted from a rule-based system to a results-oriented system based on the target setting with its public agencies (Nyamori \& Gekara, 2016). The Ghanaian system is a results-oriented system, whereby services are delivered by the public entities regionally (Osei-Kojo, 2016). The Moroccan system is results-based, and the responsibility of delivering public services is shouldered by the managers of public organisations (Errami \& Cargnello, 2018). The Nigerian system is a management control system (i.e., output control), whereby the government manages the results by reviewing the outputs of its sub-units (Ikeanyibe, 2016).

Kazakhstani's NPM reforms are classified as the most successful reforms compared with all the post-Soviet countries. However, its system is a results-based pay system and the responsibility of delivering public services is centralised across public organisations (Mussagulova \& Van der Wal, 2019). The Indonesian system is a results-oriented system based on the ideal NPM reforms. It mainly follows the stated targets in the strategic planning process for all public sub-units in gauging performance results (Turner et al., 2019). The Ethiopian system is goals-based; it is highly reliant on resultsbased management goals (Bobe et al., 2017).

The Emirati system is a results-based system that mainly focuses on performance budgeting to reach a zero-based budget at the end of the financial year. Moreover, the responsibility of delivering public services depends on the service nature following marketisation and privatisation. Marketisation means that the delivered public services to citizens are not available for market competition, while privatisation refers to partial outsourcing in the public services delivery (i.e., public-private partnership) (Sarker \& Al Athmay, 2018). Both the Uruguayan government and the Pakistani government embraced a wider adoption of private-public partnerships for delivering public services (Ramos \& Milanesi, 2020; Zahra \& Jadoon, 2016).

The Turkish system focuses extensively on inputs and outputs for delivering public services to achieve efficiency and effectiveness. Concerning the responsibility of public services delivery, the Turkish government function in different modes, involving a public agency, a private body (i.e., privatisation), and outsourcing (i.e., partial providers) based on quality and efficiency. By doing so, the Turkish government achieved accountability, responsibility, and transparency when dealing with service delivery and citizens in Turkey (Ustuner \& Yavuz, 2018). In the same vein, scholars indicated that the Malaysian government shifted from the old-fashioned public administration approach to a new one by focusing on inputs, outputs, and outcomes to achieve efficiency and respond to the citizens' concerns and interests. The Malaysian government's system of service delivery is a sub-unit that is publicly managed and controlled such as one-stop centres for performing actively and superlatively (Bianchi \& Xavier, 2017; Siddiquee et al., 2019).

Finally, the role of public participation explains the contributions of the public in improving the delivered public services by public organisations in a certain context via surveying the community's satisfaction with public services (Turner et al., 2019; Ugyel, 2014). This process might help in obtaining the community's feedback to understand the performance strengths and weaknesses of public organisations and achieve efficiency, accountability, and transparency (Junjua et al., 2019; Mahmoud et al., 2020). The Thai government emphasised the importance of collecting the citizens' feedback as customers of public services delivered by public agencies via conducting periodic surveys of their satisfaction (Sutheewasinnon et al., 2016).

In contrast, other governments, including the Kenyan government, the Nigerian government, the Emirati government, the Vietnamese government, the Egyptian government, the Indonesian government, the Albanian government, the Kazakhstani government, the Uruguayan government, the Ethiopian government, and the Moroccan government have partially directed attention for gauging the community's satisfaction about the delivered public services by public entities (Bobe et al., 2017; Errami \& Cargnello, 2018; Guga, 2018; Ikeanyibe, 2016; Mussagulova \& Van der Wal, 2019; Nyamori \& Gekara, 2016; Ramos \& Milanesi, 2020; Sarker \& Al Athmay, 2018; Turner et al., 2019; Ukeje et al., 2020; Vu et al., 2019). The Ghanaian government, the Indian government, the Mauritian government, the Turkish government, and the Malaysian government have mainly depended on the community's feedback via continuous gauging and evaluation to meet the citizens' needs and achieve efficiency, accountability, quality, and transparency (Bhiwajee \& Garavan, 2016; Bianchi \& Xavier, 2017; Osei-Kojo, 2016; Siddiquee et al., 2019; Ustuner \& Yavuz, 2018; Powell-Jackson et al., 2019). 


\section{Gaps and challenges in implementing NPM reforms}

Based on the implemented NPM reforms in developing countries, scholars discussed several gaps and challenges encountered in implementing NPM reforms. These gaps and challenges have weakened the delivery of public services in these countries. They have created dissatisfaction among citizens and distrusted relationships in the delivery system (i.e., governments and organisations) and stakeholders (i.e., citizens and public servants) (Ikeanyibe, 2016; Ukeje et al., 2020; Ramos \& Milanesi, 2020; Shaheen et al., 2017). Table 4 illustrates these gaps and challenges.

Table 4: Gaps and challenges in the implementation of NPM reforms

$\begin{array}{ll}\text { Country } & \text { Gaps and challenges } \\ \text { Thailand } & \text { Lack of leadership competencies and skills, multiple performance agreement frameworks, poor } \\ & \text { public participation, shortage of goals' achievement, absence of specific performance agreement } \\ & \text { framework, and self-based assessment of performance (Sutheewasinnon et al., 2016). } \\ \text { India } & \text { Inefficiency, ineffectiveness, goals' and job' ambiguity, bureaucracy, effect assessment system of } \\ & \text { services, unsatisfactory results, lack of leadership competence and skills in managing staff } \\ & \text { performance, lack of autonomy, poor HRM role, weak problem solvers, external pressures, and } \\ & \text { irresponsibility (Gupta et al., 2018; Powell-Jackson et al., 2019). } \\ \text { Kenya } & \text { Organisations' initiatives weakness, inefficiency, corruption, network-based relationships for } \\ & \text { rewarding, conflicting goals and principles, lack of accountability framework, irresponsibility, } \\ & \text { and poor performance planning and budgeting (Nyamori \& Gekara, 2016). } \\ \text { Ghana } & \text { Bureaucracy, inefficiency, competencies shortage, unqualified staffs, poor public participation, low } \\ & \text { education, weak infrastructure basis, poor political commitment, weak HRM role, weak of } \\ & \text { performance planning, measures, evaluation, and budgeting, lack of accountability framework, } \\ & \text { instability of leadership, goals' ambiguity, irresponsibility, and staffs' appraisal limited to } \\ & \text { promotions (Ahenkan et al., 2018; Osei-Kojo, 2016). }\end{array}$

Vietnam Irresponsibility, bureaucracy, lack of accountability, low work ethic, corruption, weak rewards system, and weak HRM role (Vu et al., 2019).

Morocco Bureaucracy, inefficiency, lack of organisational practices, corruption, weak HRM role, skills shortage of staff, lack of performance planning and budgeting, lack of autonomy, favouritism, and weak leaderships (Errami \& Cargnello, 2018).

Egypt Poor organisational practices, skills shortage, unqualified staff, and goals' and mission's ambiguity (Mostafa, 2016).

Nigeria Lack of financial autonomy, HRM autonomy, and operational autonomy, lack of accountability, bureaucracy, inefficiency, corruption, skills shortage of staff, organisational reforms are far away from NPM reforms, ethnic practices in recruitment (e.g., sentiments, nepotism, quota system, and favouritism), weak HRM role, and poor public participation (Ikeanyibe, 2016; Ukeje et al., 2020).

Kazakhstan Corruption, bureaucracy, inefficiency, low payment rates, reforms' resistance, lack of performance system, and nepotism (e.g., favouritism) (Mussagulova \& Van der Wal, 2019).

Indonesia Lack of workforce distribution, weak HRM role, inefficiency, bureaucracy, ineffectiveness, poor public participation, corruption, nepotism, collusion, overlapping among laws, regulations, and policies (Turner et al., 2019).

UAE

Malaysia Poor performance results, benchmarking, and budgeting, poor legislation, weak administrative alignment, weak HRM role, weak connections between public bodies, lack of rewards system, bureaucracy, poor implementation of a part of NPM reforms, and lack of connection between the individual goal and organisational goals (Bianchi \& Xavier, 2017; Siddiquee et al., 2019).

Turkey Lack of autonomy, political control towards senior officials' appointment, interference, change's resistance, reforms imitation without settings, ineffectiveness, lack of financial resources, lack of legal framework, bureaucracy, lack of transparency, and weak HR practices (Ustuner \& Yavuz, 2018).

Cameroon Lack of rewards system, irresponsibility towards duties and missions, shortage of qualified staff, lack of recruitment system, weak HRM role, lack of accountability, inefficiency, bureaucracy, corruption, and relationship-based network (e.g., favouritism) (Tioumagneng \& Njifen, 2019).

Pakistan Cronyism, corruption, inefficiency, bureaucracy, absence of accountability, change resistance, and duties overlapping (Shaheen et al., 2017; Zahra \& Jadoon, 2016).

Uruguay Poor implementation of NPM reforms, poor performance system (e.g., planning, evaluation, sourcing, and budgeting), and bureaucracy (i.e., procedures and normative system (Ramos \& Milanesi, 2020).

Albania Corruption, political instability, inequality, unqualified staff, lack of accountability, weak organisational alignment, low trust in public officials, and lack of autonomy (Guga, 2018). 


\begin{tabular}{cc} 
Country & Gaps and challenges \\
\hline Ethiopia & $\begin{array}{l}\text { Poor public participation, unqualified staff, poor performance planning and budgeting, weak } \\
\text { organisational practices, weak HRM role and its practices, and lack of organisational alignment }\end{array}$ \\
& $\begin{array}{l}\text { and integration (Bobe et al., 2017). } \\
\text { Lack of training system towards services reforms, inefficiency, useless government's initiatives, and } \\
\text { lack of accountability (e.g., performance assessment) (Bhiwajee \& Garavan, 2016). }\end{array}$ \\
\hline
\end{tabular}

\section{DISCUSSION AND CONCLUSION}

\section{Discussion}

The Implementation of NPM Reforms. The findings showed that the implementation of NPM reforms in developing countries varied from one country to another following the institutional settings. This partially agrees with the argument made by Leisink and Knies (2018). However, it is consistent with the arguments made by Barzelay (2000), Dunleavy et al. (2006), Hood (1990, 2005), and Lodge and Gill (2011). Moreover, there exists a group of reforms that have been translated as NPM reforms. These reforms took the form of ideology and were introduced as concepts, practices, and systems. More importantly, the NPM ideology was mainly derived from the private sector's thoughts about the management's approach to delivering public services more superiority. Moreover, the implemented NPM reforms were affected by the macro-level environment, including the governments' economies such as Kenya (Nyamori \& Gekara, 2016), Vietnam (Vu et al., 2019), and Kazakhstan (Mussagulova \& Van der Wal, 2019), international organisations' pressures such as Morocco (Errami \& Cargnello, 2018), Turkey (Ustuner \& Yavuz, 2018), and Thailand (Sutheewasinnon et al., 2016), and parties' agenda and political reforms such as Ghana (Osei-Kojo, 2016), Nigeria (Ukeje et al., 2020), and Albania (Guga, 2018), as presented in Figure 1.

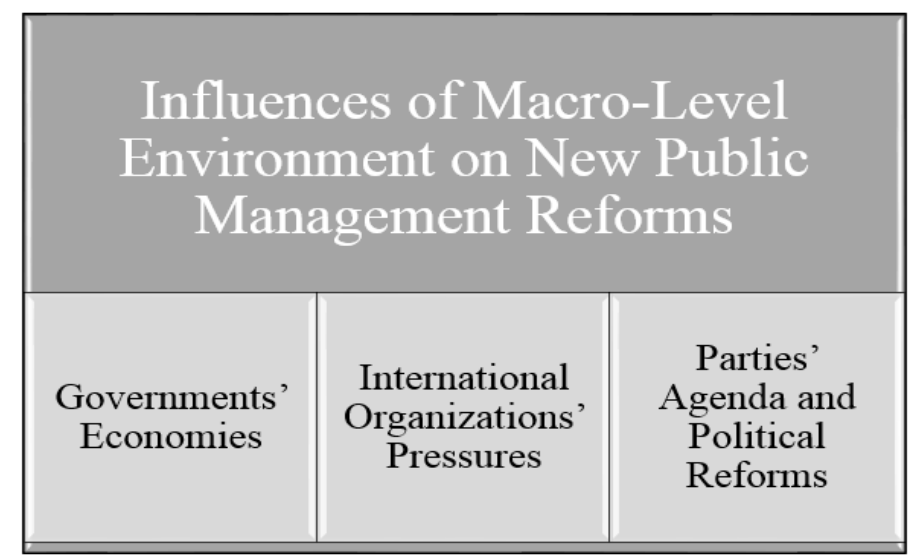

Figure 1. Influences of macro-level on NPM reforms.

Accordingly, the NPM reforms that have been introduced in the context of developing countries, included 1) disposing of bureaucracy, increasing competition between organisations, and empowering sub-units, 2) improving and reinforcing the performance management system, including planning, budgeting, evaluation, information, and results, 3) increasing efficiency, effectiveness, responsibility, accountability, transparency, and quality, 4) developing and engaging qualified public servants and empowering HRM role, 5) enabling autonomy (e.g., decentralisation activities), 6) focusing on public services delivery, accessibility, goals' clarity, and performance measures, 7) reinforcing public-private sectors partnership, 8) developing organisational initiatives, practices, and legal framework, and 9) encouraging and enhancing public participation. Figure 2 shows the NPM reforms introduced into public entities in the developing countries.

\begin{tabular}{|c|c|}
\hline \multirow{9}{*}{$\begin{array}{c}\text { New Public } \\
\text { Management } \\
\text { Reforms }\end{array}$} & $\begin{array}{l}\text { Disposing of bureaucracy, increasing competition between organizations, and } \\
\text { empowering sub-units. }\end{array}$ \\
\hline & $\begin{array}{l}\text { Improving and reinforcing the performance management system, including } \\
\text { planning, budgeting, evaluation, information, and results. }\end{array}$ \\
\hline & $\begin{array}{l}\text { Increasing efficiency, effectiveness, responsibility, accountability, transparency, } \\
\text { and quality. }\end{array}$ \\
\hline & Developing and engaging qualified public servants and empowering HRM role. \\
\hline & Enabling autonomy (e.g., decentralization activities). \\
\hline & $\begin{array}{l}\text { Focusing on public services delivery, accessibility, goals' clarity, and performance } \\
\text { measures. }\end{array}$ \\
\hline & Reinforcing public-private sectors partnership. \\
\hline & Developing organizational initiatives, practices, and legal framework. \\
\hline & Encouraging and enhancing public participation. \\
\hline
\end{tabular}

Figure 2. The NPM reforms in the developing countries. 
The Gaps and Challenges of The Implementation of NPM Reforms. The review's findings concluded that most of the developing countries failed to implement the NPM reforms at a micro-level environment. Scholars pointed out that implementing NPM reforms has been typically a dead letter in these developing countries (Ramos \& Milanesi, 2020). Furthermore, public leaderships and servants have not considered and dealt with the reforms as a new approach for managing and operating public entities to improve public services (Ikeanyibe, 2016). This led to poor services, stakeholders' dissatisfaction (i.e., citizens and servants), and created a distrusted relationship between governments and the public (Guga, 2018; Powell-Jackson et al., 2019; Sutheewasinnon et al., 2016; Ukeje et al., 2020). The major gaps and challenges involved inefficiency, ineffectiveness, bureaucracy, lack of autonomy, corruption, lack of transparency and accountability, a weak legal framework, irresponsibility, and poor public participation (Bobe et al., 2017; Errami \& Cargnello, 2018; Nyamori \& Gekara, 2016; Osei-Kojo, 2016; Turner et al., 2019; Ustuner \& Yavuz, 2018; Vu et al., 2019).

More specifically, ineffectiveness, inefficiency, lack of accountability, and irresponsibility resulted in goals' achievement shortage, goals' and jobs' ambiguity, poor organisational practices, lack of competencies and skills, and performance management system weaknesses (Ahenkan et al., 2018; Gupta et al., 2018; Mostafa, 2016; Mussagulova \& Van der Wal, 2019; Siddiquee et al., 2019; Sutheewasinnon et al., 2016). In addition, corruption, bureaucracy, lack of autonomy, and a weak legal framework resulted in centralisation activities, employee dissatisfaction, ethnic practices (e.g., Wasta, cronyism, sentiments, nepotism, quota system, and collusion), change resistance, instability of leadership, and poor organisational alignment (Bhiwajee \& Garavan, 2016; Bianchi \& Xavier, 2017; Errami \& Cargnello, 2018; Mussagulova \& Van der Wal, 2019; Shaheen et al., 2017; Turner et al., 2019; Ukeje et al., 2020; Ustuner \& Yavuz, 2018; Vu et al., 2019; Zahra \& Jadoon, 2016). Figure 3 summarizes the gaps and challenges of the implementation of NPM reforms in developing countries.

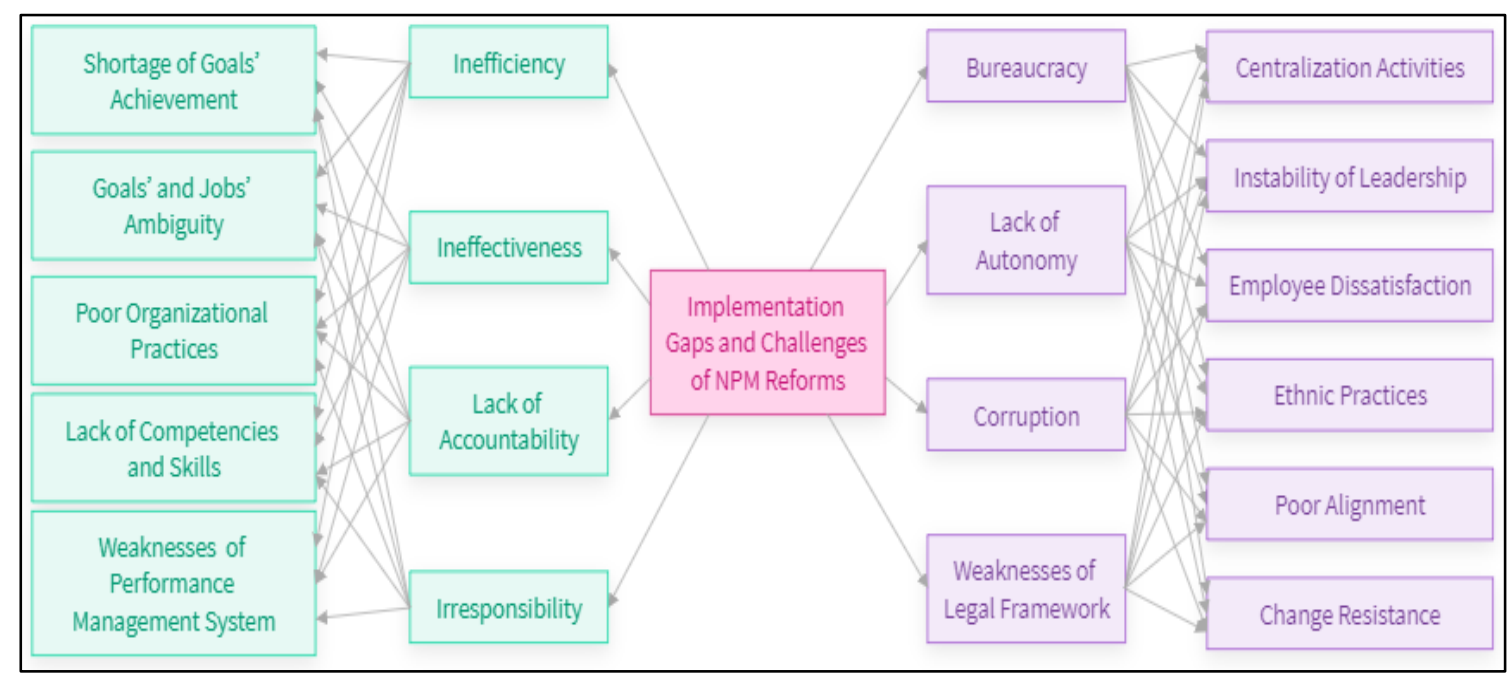

Figure 3. The gaps and challenges of the implementation of the NPM reforms.

The Effects and Implications on HRM. Scholars asserted that HR is one of the key resources to achieve excellent performance (Delaney \& Huselid, 1996). It is confirmed that the performance of public organisations relies heavily on HR competencies and skills (El-Ghalayini, 2017; Thompson, 2017), which are managed and operated by HRM functions (e.g., HR practices and policy) (Becker \& Gerhart, 1996). Moreover, scholars argued that the implementation differences of NPM reforms drive to modelling HRM role differently based on the institutional settings (Leisink \& Knies, 2018). More specifically, the mentioned gaps and challenges have significantly weakened HRM practices and policy (Bobe et al., 2017; Errami \& Cargnello, 2018; Powell-Jackson et al., 2019; Ukeje et al., 2020). Consequently, the shortage of goals' achievement, goals' and jobs' ambiguity, lack of competencies and skills, dissatisfaction of staff, poor organisational practices and alignment, ethnic practices, leaderships' change resistance, centralisation activities, and performance management system weaknesses led to weakening the staff assessment system, training and development programmes, rewards system, workforce distribution and recruitment, and promotions and career path development towards leadership positions (Ahenkan et al., 2018; Bhiwajee \& Garavan, 2016; Errami \& Cargnello, 2018; Ikeanyibe, 2016; Nyamori \& Gekara, 2016; Siddiquee et al., 2019; Tioumagneng \& Njifen, 2019; Turner et al., 2019; Vu et al., 2019; Ustuner \& Yavuz, 2018).

From the review's findings, firstly, it is notable that the incentivisation component that mainly focuses on compensating and rewarding public servants' performance was partially neglected; salary rates in many developing countries are limited, and others are cut down. Secondly, the competition component that refers to own best qualifications and competencies of public servants in public organisations, who are highly motivated to deliver public services efficiently; the qualifications, competencies, and skills of public organisations' servants in many developing countries are limited, and leadership positions fluctuate with incapable people often appointed. Thirdly, the disaggregation component that relatively explains HRM autonomy indicates that the HRM of public organisations in several developing countries is a weak unit that failed to achieve its strategic role, as shown in Figure 4. 


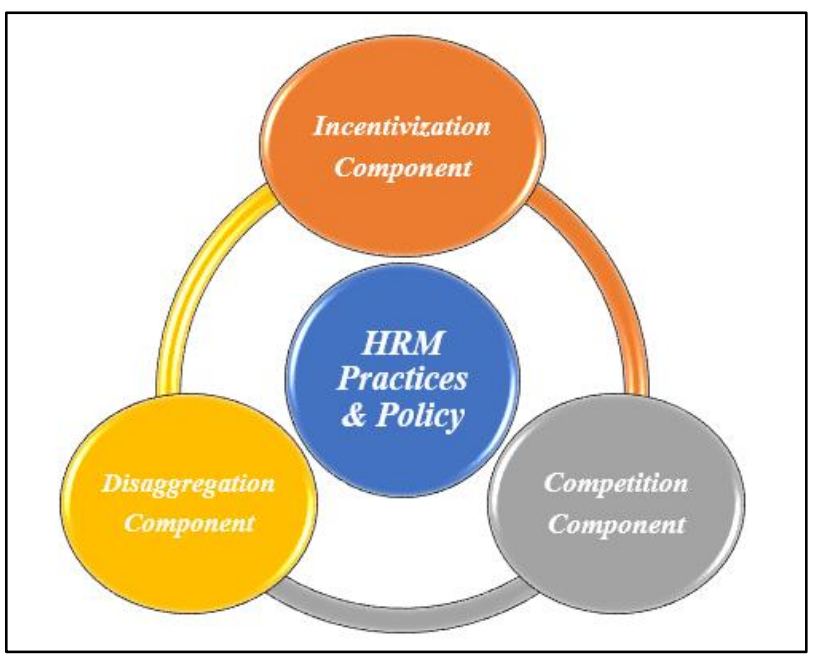

Figure 4. The NPM components and HRM.

Few governments in the developing countries introduced a set of reforms on HRM of public organisations in the developing countries. Nevertheless, many public organisations in developing countries focus on HRM practices and policy, namely HR regulations, performance appraisal, rewards system, training and development programmes, and managing public staff affairs. The HRM reforms as an integral part of NPM ideology need to be reformed to regulate, manage, reward, develop, and evaluate public servants' performance towards public services delivery.

Thus, the NPM components of incentivisation, competition, and disaggregation are currently the contemporary knowledge gaps for future research in HRM to deliver public services superiority. The NPM components in the developing countries have been adopted to establish poor reforms, especially HRM reforms. Therefore, the current gaps in knowledge should be considered in future research to improve HRM regulations and management towards public services delivery.

The first promising direction for future research would be incentivisation, namely rewards and compensations system for the public servants' performance. Previous studies referred to the significant role of rewards and compensations in motivating the public servants' performance. However, few studies focused on this direction, with many studies not clarifying a method for rewarding and compensating public servants' performance. The reward and compensation process relies on relationship-based, low salary rates, and lack of a rewards system (Bianchi \& Xavier, 2017; Mussagulova \& Van der Wal, 2019; Nyamori \& Gekara, 2016; Tioumagneng \& Njifen, 2019; Vu et al., 2019). Other studies did not discuss incentivisation as a major component of NPM components. Therefore, future studies should focus on policy, structure, and procedures for rewarding and compensating.

The second direction would be competition, namely qualifications, competencies, and public servants' and leaders' skills. The quality of public staff is important because HRM is the backbone of any organisation. However, it is notable that public organisations suffer from a shortage of qualifications, competencies, and skills at all levels. In other words, there are shortages and weaknesses in the public servants' qualifications, competencies, and skills, even more so among public leaders in many developing countries (Ahenkan et al., 2018; Bobe et al., 2017; Errami \& Cargnello, 2018; Guga, 2018; Gupta et al., 2018; Mostafa, 2016; Osei-Kojo, 2016; Powell-Jackson et al., 2019; Sutheewasinnon et al., 2016; Tioumagneng \& Njifen, 2019). Training and development programmes are the most significant methods to develop the staff's knowledge, ability, and skills. Therefore, training and development aspects, including formal training, informal training (Bhiwajee \& Garavan, 2016), training resources, training budget (Guga, 2018), and training quality (Bobe et al., 2017) might be taken into consideration in training and developing public servants and leaders.

The third direction would be disaggregation, namely the autonomy and role of HRM. The HRM of public organisations in developing countries is weak. The HRM lacks autonomy which reflected in poor workforce distribution, poor HR policy, weak criteria in the staff assessment, and leadership instability (Ahenkan et al., 2018; Bianchi \& Xavier, 2017; Bobe et al., 2017; Errami \& Cargnello, 2018; Gupta et al., 2018; Powell-Jackson et al., 2019; Ikeanyibe, 2016; Osei-Kojo, 2016; Siddiquee et al., 2019; Tioumagneng \& Njifen, 2019; Turner et al., 2019; Ukeje et al., 2020). The HRM is a set of management decisions about practices and policy that manage and regulate public staff's efforts and contributions (Boselie et al., 2019), including the staff's distribution (Turner et al., 2019), assessment of the staff' performance, leadership continuity and availability (Osei-Kojo, 2016), and HR policy (Gupta et al., 2018). Thus, future research could focus on these aspects of HRM.

These three directions of NPM components are the prominent directions for future research as important reforms on HRM under NPM reforms. 


\section{Conclusion}

The findings highlighted the implementation of NPM reforms, as well as the gaps and challenges in implementing NPM reforms as presented in Table 4. The review's findings concluded that the NPM reforms of the developing world are hesitantly implemented in accordance with the micro-level environment and the macro-level environment, which, in turn, generate gaps and challenges in NPM reforms. Accordingly, these gaps and challenges played a major role in affecting and implicating HRM practices and policy.

These gaps and challenges affected and implicated HRM. HRM deficits involve inaccurate results of the performance appraisal process, unequal rewards and low wages, shortage of training and development programmes, weaknesses of workforce management and distribution, unstable and inexpert leadership positions, and breaking of HR policy. The review's findings identified three directions of the NPM components as future research directions, namely incentivisation, competition, and disaggregation. These three components shape the HRM (i.e., HR practices and policy) such as performance appraisal, motivational and rewarding initiatives, training and development, workforce management, succession management, and HR policy.

The originality of the lessons and experiences of the implementations of NPM reforms in this paper has practical and academic significance. Practically, the public administrators and HR managers are required to address the gaps and challenges of the NPM reforms, as well as the weaknesses of HRM to fulfil the public expectations. Likewise, governments are required to support and control the implementation of NPM reforms in developing countries based on the macro and micro levels. Academically, scholars should investigate the current NPM reforms, particularly the NPM components in public administrations based on the mentioned future research directions to highlight the status of HRM. This is because the literature of NPM of public entities is very limited in developing countries, especially the NPM components.

\section{REFERENCES}

Ahenkan, A., Tenakwah, E.S., \& Bawole, J.N. (2018). Performance management implementation challenges in Ghana's local government system: Evidence from the Sefwi Wiawso Municipal Assembly. International Journal of Productivity and Performance Management 67(3), 519-535.

Ain, N., Vaia, G., DeLone, W. H., \& Waheed, M. (2019). Two decades of research on business intelligence system adoption, utilisation and success-A systematic literature review. Decision Support Systems, 125, 113.

Aoki, N. (2019). After all these years, what has happened to the international prevalence of NPM-inspired managerial practices? International Journal of Public Sector Management, 32(4), 403-417.

Azhar, D., Mendes, E., \& Riddle, P. (2012, September). A systematic review of web resource estimation. In Proceedings of the 8th International Conference on Predictive Models in Software Engineering, 49-58.

Barzelay, M. (2000). The new public management: Improving research and policy dialogue. Berkeley: University of California Press.

Becker, B., \& Gerhart, B. (1996). The impact of human resource management on organisational performance: Progress and prospects. Academy of management journal, 39(4), 779-801.

Bhiwajee, L.S. \& Garavan, T.N. (2016). The empowering of public sector officers in the Mauritian public sector in the context of reforms: How far has management education helped? European Journal of Training and Development, 40(4), 262-283.

Bianchi, C., \& Xavier, J. A. (2017). The design and execution of performance management systems at state level: A comparative analysis of Italy and Malaysia. International Journal of Public Administration, 40(9), 744-755.

Blom, R., Kruyen, P. M., Van der Heijden, B. I., \& Van Thiel, S. (2020). One HRM fits all? A meta-analysis of the effects of HRM practices in the public, semipublic, and private sector. Review of Public Personnel Administration, 40(1), 3-35.

Bobe, B.J., Mihret, D.G. \& Obo, D.D. (2017). Public-sector reforms and balanced scorecard adoption: an Ethiopian case study. Accounting, Auditing \& Accountability Journal, 30(6), 1230-1256.

Boselie, P., Van Harten, J., \& Veld, M. (2019). A human resource management review on public management and public administration research: stop right there... before we go any further.... Public Management Review, 1-18.

Cantarelli, P., Bellé, N., \& Belardinelli, P. (2020). Behavioral public HR: Experimental evidence on cognitive biases and debiasing interventions. Review of Public Personnel Administration, 40(1), 56-81.

Delaney, J. T., \& Huselid, M. A. (1996). The impact of human resource management practices on perceptions of organisational performance. Academy of Management journal, 39(4), 949-969.

Dunleavy, P., \& Hood, C. (1994). From old public administration to new public management. Public money \& management, 14(3), 9-16.

Dunleavy, P., Margetts, H., Bastow, S., \& Tinkler, J. (2006). New public management is dead-long live digital-era governance. Journal of public administration research and theory, 16(3), 467-494.

El-Ghalayini, Y. (2017). Human resource management practices and organisational performance in public sector organisation. Journal of business studies quarterly, 8(3), 65.

Errami, Y., \& Cargnello, C. E. (2018). The pertinence of new public management in a developing country: The healthcare system in Morocco. Canadian Journal of Administrative Sciences, 35(2), 304-312.

Fletcher, L., Bailey, C., Alfes, K., \& Madden, A. (2020). Mind the context gap: a critical review of engagement within 
the public sector and an agenda for future research. The International Journal of Human Resource Management, 31(1), 6-46.

Fryer, K., Antony, J., \& Ogden, S. (2009). Performance management in the public sector. International Journal of Public Sector Management, 22(6), 478-498.

Guga, E. (2018). Local government modernisation in Albania: Historical background and the territorial reform 2015 2020. International Journal of Public Sector Management, 31(4), 466-506.

Haynes, P. (2003). Managing complexity in the public services. Maidenhead: Open University Press.

Hoehle, H., Scornavacca, E., \& Huff, S. (2012). Three decades of research on consumer adoption and utilisation of electronic banking channels: A literature analysis. Decision Support Systems, 54(1), 122-132.

Hood, C. C. (1990). A public Management for all seasons? Public Administration, 69, 3-19.

Hood, C. (1995). The "new public management" in the 1980s: Variations on a theme. Accounting, organisations and society, 20(2-3), 93-109.

Hood, C. (2005). Public management: The Word, the movement, the science. In E. Ferlie, L. Lynn, \& C. Pollitt (Eds.), Oxford Handbook of Public Management. Oxford, UK: Oxford University Press.

Ikeanyibe, O. M. (2016). New public management and administrative reforms in Nigeria. International Journal of Public Administration, 39(7), 563-576.

Kitchenham, B., Brereton, O. P., Budgen, D., Turner, M., Bailey, J., \& Linkman, S. (2009). Systematic literature reviews in software engineering-a systematic literature review. Information and software technology, 51(1), 7-15.

Komutputipong, N., \& Keerasuntonpong, P. (2019). Accountability perception of Thai Government: to whom and what counts. Journal of Public Budgeting, Accounting \& Financial Management, 31(1), 45-65.

Lapuente, V., \& Van de Walle, S. (2020). The effects of new public management on the quality of public services. Governance, 33(3), 461-475.

Le Grand, J. (2003). Motivation, agency, and public policy: of knights and knaves, pawns and queens. Oxford University Press on Demand.

Leisink, P., \& Knies, E. (2018). Public Personnel Reforms and Public Sector HRM in Europe. In the Palgrave Handbook of Public Administration and Management in Europe, 243-259. Palgrave Macmillan, London.

Lodge, M., \& Gill, D. (2011). Toward a new era of administrative reform? The myth of post-NPM in New Zealand. Governance, 24(1), 141-166.

Mahmoud, M. M. H., Othman, R., \& Mahmoud, M. A. T. (2020). Performance Management System of Jordanian Public Sector Organisations: Greater Amman Municipality's (GAM) Experience. International Journal of Human Resource Studies, 10(2), 308-329.

Miller, G. (2000). Above politics: Credible commitment and efficiency in the design of public agencies. Journal of Public Administration Research and Theory, 10(2), 289-328.

Mostafa, A. M. S. (2016). High-performance HR practices, work stress and quit intentions in the public health sector: Does person-organisation fit matter? Public Management Review, 18(8), 1218-1237.

Nyamori, R. O., \& Gekara, V. O. (2016). Performance contracting and social capital (re) formation: A case study of Nairobi City Council in Kenya. Critical Perspectives on Accounting, 40, 45-62.

Osei-Kojo, A. (2017). E-government and public service quality in Ghana. Journal of Public Affairs, 17(3).

Pavan, A., Reginato, E., \& Fadda, I. (2014). The Implementation Gap of NPM reforms in Italian local governments. An Empirical Analysis, Franco Angeli, Srl, Milano, Italy.

Pierre, J. (Ed.). (2000). Debating governance: Authority, steering, and democracy. OUP Oxford.

Pollitt, C. (1993). Managerialism and the public services: The Anglo-American experience. Oxford, UK: Blackwell.

Powell-Jackson, T., Purohit, B., Saxena, D., Golechha, M., Fabbri, C., Ganguly, P. S., \& Hanson, K. (2019). Measuring management practices in India's district public health bureaucracy. Social Science \& Medicine, 220, 292-300.

Ramos, C., \& Milanesi, A. (2020). The neo-Weberian state and the neodevelopmentalist strategies in Latin America: The case of Uruguay. International Review of Administrative Sciences, 86(2), 261-277.

Roh, J. (2018). Improving the government performance management system in South Korea: Focusing on central government agencies. Asian Education and Development Studies, 7(3), 266-278.

Rosenberg Hansen, J., \& Ferlie, E. (2016). Applying strategic management theories in public sector organisations: Developing a Typology. Public Management Review, 18(1), 1-19.

Sarker, A. E., \& Al Athmay, A. A. A. R. A. (2018). The changing facets of public administration in the United Arab Emirates. International Journal of Public Administration, 41(10), 832-844.

Shaheen, S., Bashir, S., \& Khan, A. K. (2017). Examining organisational cronyism as an antecedent of workplace deviance in public sector organisations. Public Personnel Management, 46(3), 308-323.

Siddiquee, N. A., Xavier, J. A., \& Mohamed, M. Z. (2019). What works and why? Lessons from public management reform in Malaysia. International Journal of Public Administration, 42(1), 14-27.

Suhail, A., \& Steen, T. (2018). The Effects of HR Autonomy on the Discrepancy Between Intended and Implemented HRM Practices in the Public Sector: An Exploratory Study of Public Hospitals in Pakistan. In EGPA Conference: Study Group III: Public Personnel Policies, Date: 2018/09/05-2018/09/07, Location: Laussane, Switzerland.

Sutheewasinnon, P., Hoque, Z., \& Nyamori, R. O. (2016). Development of a performance management system in the Thailand public sector: Isomorphism and the role and strategies of institutional entrepreneurs. Critical Perspectives on Accounting, 40, 26-44.

Thompson, J. R. (2017). Value shifts in public sector human resource management: A congressional perspective. Review 
of Public Personnel Administration, 37(4), 375-404.

Tioumagneng, A., \& Njifen, I. (2019). Employee involvement in the public administrative sector: an exploration of the engagement drivers in Cameroon. International Review of Administrative Sciences, 0020852319838037.

Truss, C. (2013). The distinctiveness of human resource management in the public sector. In N. a. Burke, Human Resource Management in the Public Sector (pp. 17-34). Cheltenham: Edward Elgar Publishing Limited.

Turner, M., Prasojo, E., \& Sumarwono, R. (2019). The challenge of reforming big bureaucracy in Indonesia. Policy Studies, 1-19.

Ugyel, L. (2014). Explaining hybridity in public administration: an empirical case of Bhutan's civil service. Public Administration and Development, 34(2), 109-122.

Ukeje, I. O., Ndukwe, C., Emma, C., Ogbulu, U., \& Onele, J. C. (2020). Public service recruitment practices and implications for sustainable development in Ebonyi state, Nigeria. International Journal of Public Administration, 43(4), 361-372.

Ustuner, Y., \& Yavuz, N. (2018). Turkey's Public Administration Today: An Overview and Appraisal. International Journal of Public Administration, 41(10), 820-831.

Vu, T. A., Plimmer, G., Berman, E., \& Sabharwal, M. (2019). Managing employee performance in transition economies: A study of Vietnamese public organisations. Public Administration and Development, 39(2), 89-103.

Zahra, A. \& Jadoon, M.Z.I. (2016). Autonomy of public agencies in Pakistan: does structure matter? International Journal of Public Sector Management, 29(6), 565-581.

\section{CONFLICT OF INTEREST}

The author(s), as noted, certify that they have NO affiliations with or involvement in any organisation or agency with any financial interest (such as honoraria; educational grants; participation in speakers' bureaus; membership, jobs, consultancies, stock ownership, or other equity interest; and expert testimony or patent-licensing arrangements), or nonfinancial interest (such as personal or professional relationships, affiliations, expertise or beliefs) in the subject matter or materials addressed in this manuscript.

\section{AUTHORS' BIOGRAPHY}

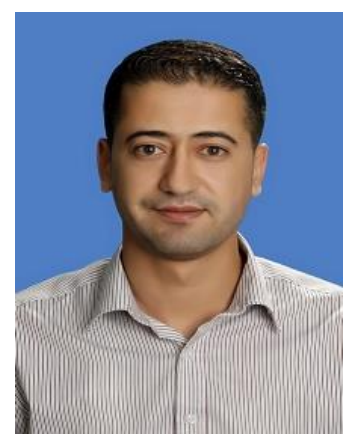

Mo'men Hani Mahmoud is a PhD student at the Graduate School of Business, Universiti Sains Malaysia. His reseach interests are in the areas of human resource management and performance of public organisations.

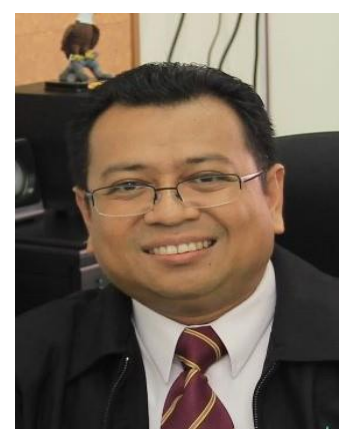

Rosly Othman, PhD is a senior lecturer at the Graduate School of Business, Universiti Sains Malaysia. His main research interests are in the area of operations management. 